\title{
PENGARUH PEMBELAJARAN BERBASIS MASALAH (PROBLEM BASED LEARNING) TERHADAP KEMAMPUAN BERPIKIR KRITIS SISWA PADA MATA PELAJARAN PKn KELAS VI DI SDN KOTA SUMENEP \\ Tri Sutrisno \\ IAIN Madura \\ E-mail: tri.sutrisno@iainmadura.ac.id
}

\begin{abstract}
Abstrak: Penelitian ini bertujuan untuk menilai pengaruh penggunaan model problem based learning untuk keterampilan berpikir kritis dalam kewarganegaraan tentang sistem pemerintahan. Objek penelitian ini adalah kelas VI SDN Kolor II Sumenep. Termasuk 2 kelas yang digunakan dalam penelitian ini meliputi, kelas VIA SDN Pajagalan sebagai percobaan kelas I, VI A sebagai kelompok eksperimen dan kelompok kontrol VIB SDN Kolor II. Tes kelas yang dimaksudkan adalah kelas yang digunakan untuk menguji instrumen yang akan digunakan untuk mengambil data keterampilan berpikir kritis siswa. Pendekatan penelitian kuantitatif ini, syarat-syarat nilai perolehan kemampuan tes untuk skor keterampilan berpikir kritis atau nilai-nilai dijumlahkan dan dianalisis menggunakan t-test dua sampel independen. Pada validitas tes diperoleh hitungan $\geq \mathrm{r} \mathrm{r}$ - kritis $(0,349)$, instrumen tersebut valid dan dapat digunakan. Dalam pengujian andal hitung $r>r$ kritis $(0,60)$, yaitu nilai Alpha 0,966 yang berarti lebih besar dari 0,60. Dengan demikian seluruh instrumen barang bisa diandalkan. Hasil pengujian hipotesis dapat dilihat dari data yang telah dianalisis dengan t 3,730>t-tabel 2,00 $(\alpha=0,05)$. Dapat disimpulkan bahwa probabilitas kesalahan dalam penelitian ini masih di bawah 0,05 . Pengujian hipotesis dapat diputuskan, bahwa dengan harga tinggi 3,730 t-test memiliki tingkat signifikansi 0,000 , yang ternyata posisinya masih jauh di bawah nilai $\alpha=0,05$. Oleh karena itu penelitian ini berhasil menolak H0 pada tingkat signifikansi 5\%. Lebih lanjut, dapat disimpulkan bahwa H1 terbukti benar. Berarti dalam kelompok eksperimen pretest posttest kelompok eksperimen adalah 54,38 adalah 74,38. Sedangkan rata-rata kelompok kontrol pretest adalah 51,94. Grup postes adalah 66,94. Ini adalah bukti bahwa terjadi peningkatan pada kelas eksperimen yang telah diberi perlakuan dengan model problem based learning. Dengan demikian kita dapat menyimpulkan kemampuan keterampilan berpikir kritis siswa dalam kelompok eksperimen lebih tinggi daripada kelompok kontrol. Model problem based learning berpengaruh positif terhadap kemampuan siswa untuk keterampilan berpikir kritis.
\end{abstract}

\section{Kata kunci: Model Problem Based Learning, Kemampuan Berpikir Kritis}

Abstract: This study aims to assess the effect of the use of problem solving based learning model for critical thinking skills in civics about the system of goverment. Object of this research is a class VI SDN Kolor II Sumenep. Includes 2 classes used in this study include, VIA SDN Pajagalan class as a class I trial, VI A as an experimental group and a control group VIB SDN Kolor II . Class tests are intended class is used to test the instruments to be used to retrieve data critical thinking skills of students. This quantitative research approaches, the terms of the acquisition value of the test 's ability to critical thinking skills scores or values are summed and analyzed using t-test two independent samples. On the validity of the test obtained count $\geq \mathrm{r} \mathrm{r}$ - critical ( 0.349 ), the instrument as valid and can be used. In the test reliably count $r>r$ critical ( 0.60 ), namely Alpha value of 0.966 which means greater than 0.60 . Thus the entire item instrument is reliable. Results of hypothesis testing can be seen from the data that has been analyzed by t $3.730>t$-table $2.00(\alpha=0.05)$. It 


\title{
ELSE (Elementary School Education Journal) \\ Volume 3 Nomor 2 Agustus 2019 \\ P-ISSN: 2581-1800 E-ISSN: 2597-4122 \\ Email: else@um-surabaya.ac.id
}

\begin{abstract}
can be concluded that the probability of error in this study still below 0.05 . Hypothesis testing can be decided, that with the high price of 3.730 t-test has significance level of 0.000 , which turned out to be his position is still far below the value of $\alpha=0.05$. This study therefore managed to reject $\mathrm{H} 0$ at significance level of $5 \%$. Furthermore, it can be concluded that the $\mathrm{H} 1$ was proved right. Mean in the experimental group pretest posttest experimental group is 54.38 is 74.38. While the control group mean pretest is 51.94. Postes group is 66.94. This is evidence that an increase in the experimental class that has been given treatment with problem solving-based learning model. Thus we can conclude critical thinking skills abilities of students in the experimental group was higher than the control group. Problem solving-based learning model a positive effect on students' ability tocritical thinking skills.
\end{abstract}

Keywords: Problem Based Learning Model, Critical Thinking Skills

Submitted on: 2019-09-24

Accepted on: 2019-09-25

\section{PENDAHULUAN}

Menurut Undang-undang Sistem Pendidikan Nasional (Sisdiknas) Nomor 20 Tahun 2003 dijelaskan bahwa pendidikan nasional berfungsi mengembangkan kemampuan dan membentuk watak serta peradaban bangsa yang bermartabat dalam rangka mencerdaskan kehidupan bangsa. Selain itu, disebutkan dalam undang-undang tersebut bahwa pendidikan nasional bertujuan untuk mengembangkan potensi peserta didik agar menjadi manusia yang beriman dan bertaqwa kepada Tuhan Yang Maha Esa, berakhlak mulia, sehat, berilmu, cakap, kreatif, mandiri, dan menjadi warga negara yang demokratis serta bertanggungjawab.

Untuk mencapai tujuan tersebut, maka kualitas pendidikan perlu untuk terus ditingkatkan. Kualitas pendidikan ini terkait dengan kualitas proses dan kualitas hasil. Kualitas proses dapat dicapai apabila proses pembelajaran berlangsung secara efektif dan peserta didik dapat menghayati serta menjalani proses pembelajaran secara bermakna. Kualitas hasil dapat dilihat pada unjuk kerja peserta didik yang menunjukan kecakapan hidup dan kompetensi dengan tingkat penguasaan yang tinggi; yang meliputi pemahaman dan penghayatan pengetahuan, keterampilan, sikap, dan juga nilai-nilai terhadap tugastugas belajar sesuai dengan kebutuhan peserta didik dalam kehidupannya dan tuntutan yang ada di masyarakat (dunia kerja).

Peningkatan kualitas sumber daya manusia dalam sebuah bangsa juga tidak dapat di pisahkan dengan pendidikan.Hal ini tidak dapat di abaikan karena pendidikan adalah dasar atau fondamen dari masyarakat yang berkualitas (Tilar, 2001:3). Upaya peningkatan 
kualitas sumber daya manusia tidak dapat dilakukan dengan hanya memberikan kesempatan memperoleh pendidikan, akan tetapi harus di sertai dengan peningkatan mutu pendidikan itu sendiri. Pembangunan pendidikan, merupakan salah satu aspek yang sangat penting dalam rangka mewujudkan kualitas sumber daya manusia.Suatu negara yang maju pada umumnya lebih mengutamakan melalui pembangunan dimulai dari pembangunan manusia seutuhnya melalui dunia pendidikan.Suatu negara yang telah melaksanakan pembangunan mulai dari dunia pendidikan saat ini sudah tampak kemajuannya yang sangat pesat, seperti Jepang, Singapora, Malaysia, dan sebagainya.

Sementara itu, menyadari akan pentingnya peningkatan kualitas SDM sejak usia dini khususnya sekolah tingkat dasar (SD), pemerintah telah melakukan upaya-upaya di antaranya dengan program-program peningkatan mutu pendidikan. Dalam bidang pendidikan pembenahan yang dilakukan antara lain 1) dalam bidang sarana prasarana pemerintah telah melakukan perbaikan dan pengadaan gedung-gedung sekolah serta pengadaan buku-buku pelajaran, 2) dalam bidang kompetensi tenaga kependidikan, pemerintah dengan semangat telah menyelenggarakan pelatihan-pelatihan bagi kepala sekolah, guru dan tenaga kependidikan lainnya, dan 3) dalam bidang kurikulum, pemerintah juga telah melakukan revisi terhadap kurikulum1994 yang berganti menjadi kurikulum 2004 yaitu kurikulum berbasis kompetensi (KBK) dan dalam waktu dekat hingga sekarang kurikulum yang di berlakukan adalah kurikulum tingkat satuan pendidikan (KTSP), bahkan berdasarkan pertimbangan dan pemikiran KTSP kembali mendapat perbaikan dengan hadirnya Kurikulum 2013.

Selain bidang diatas, kegiatan pembelajaran juga ikut memberikan kontribusi terhadap mutu pendidikan. Model-model pembelajaran yang hendak diterapkan oleh guru menjadi bahan kajian penting dalam pendidikan. Pelaksanaan pembelajaran yang fungsional dan efektif merupakan salah satu aspek dalam upaya meningkatkan mutu pendidikan. Dalam pelaksanaan tersebut, terjadi interaksi antara guru dalam keberadaannya untuk mengajar dan siswa dalam keberadaannya untuk belajar. Mengajar dalam hal ini, tentulah dengan menggunakan metode tertentu sebagai salah satu komponen dalam mencapai tujuan pembelajaran, yang dalam pelaksanaannya tidaklah terlepas dari jenis pendekatan yang dilaksanakan. Oleh karena itu, peranan yang sangat menentukan dari penggunaan suatu metode pengajaran yang disertai jenis pendekatan tertentu, memerlukan metode pengajaran yang serasi dan jenis pendekatan yang tepat. 


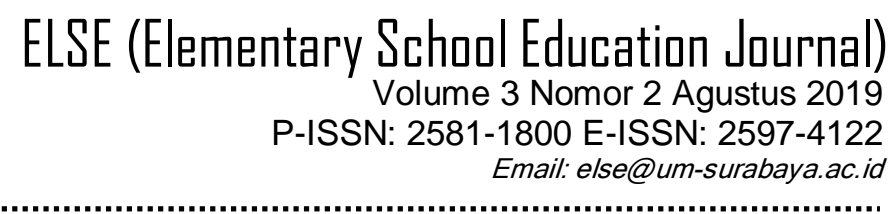

Metode pengajaran dapat dipahami sebagai strategi dalam proses belajar mengajar (Sardiman, 2000: 21). Metode pengajaran adalah kerangka konseptual yang melukiskan prosedur yang sistematis dalam mengorganisasikan pengalaman belajar untuk mencapai tujuan pembelajaran tertentu, dan berfungsi sebagai pedoman bagi para perancang pembelajaran dan para pengajar dalam merencanakan dan melaksanakan aktivitas belajar mengajar.

Oleh karena itu, sebagai guru harus mencari atau memilih metode pembelajaran/metode mengajar yang tepat dan sesuai dengan kondisi siswa serta materi yang disampaikannya. Sebab dengan metode pembelajaran yang sama tetapi karakter siswa berbeda, hasilnya akan berbeda. Demikian juga untuk materi yang berbeda seorang guru tidak bisa menerapkan metode pembelajaran yang sama.

Metode pembelajaran yang dipilih diharapkan mempertimbangkan kemudahan bagi siswa dalam menangkap materi yang disampaikan oleh guru sehingga dapat diaplikasikan dalam kehidupan sesuai dengan kaidah yang berlaku Hal tersebut hendaknya melibatkan dunia nyata sebagai suatu konteks belajar bagi siswa. Dengan demikian, penyajian suatu masalah yang autentik dan bermakna akan dapat memberikan kemudahan kepada siswa untuk melakukan penyelidikan dan penemuan.

Karaktersitik mata pelajaran sangat penting dipertimbangkan dalam pembelajaran, karena setiap mata pelajaran memiliki tujuan yang harus di capai, demikian juga setiap mata pelajaran mempunyai pola khas yang menuntut cara penyampaian yang berbeda satu dengan yang lainnya. Pendidikan kewarganegaraan yang bertujuan untuk membentuk warga negara yang baik, yaitu warga negara yang memiliki pengetahuan, ketrampilan, dan karakter dengan konsep dan prinsip pendidikan kewaarganegaraan, maka dalam tiga dimensi di atas harus ada penekanan dalam proses pembelajaran yang mengarah kepada karakter walaupun bukan berarti meniadakan dimensi kognitif dan ketrampilan.

Winaputra (2005: 1) menyatakan bahwa tugas PKn dengan paradigma baru adalah mengembangkan pendidikan demokrasi dengan tiga fungsi pokok yaitu mengembangkan kecerdasan warganegara (civic intelligence), membina tanggung jawab warga negara (civic responsibility) dan mendorong partisipasi warganegara (civic participation).Dimensi kecerdasan warganegara tidak hanya sebatas rasional saja, melainkan juga dimensi spiritual, emosional dan sosial sehingga PKn bercirikan multidimensi.Hal ini menjadi tugas 
guru untuk memberikan bimbingan kepada siswa tentang nilai-nilai pancasila dan budaya masyarakat Indonesia.

Menurut Savage (1996:9-10) ada tiga fungsi utama dalam pendidikan kewarganegaraan, yaitu sebagai berikut.

1 Menumbuhkan komitmen dalam diri generasi muda untuk membuat keputusan secara demokratis.

2 Menumbuhkan sifat dan sikap kritis dalam melakukan sesuatu.

3 Menghasilkan generasi muda yang siap bergabung dalam ranah pelayanan dan publik secara aktif.

Pembelajaran PKn juga menekankan hak dan tanggungjawab warga negara dalam kehidupan berbangsa dan bernegara. Tanggungjawab ini meliputi tanggungjawab pribadi maupun kewarganegaraan. Hal ini tentu memerlukan pengetahuan dan ketrampilan intelektual dalam berperan serta. Hal ini yang diharapkan oleh pembelajaran PKn. Pelajaran PKn mempunyai tujuan seperti dituliskan dalam Peraturan Menteri Pendidikan Nasional Nomor 22 tahun 2006 yaitu agar peserta didik memiliki kompetensi sebagai berikut.

1 Berfikir secara kritis, rasional, dan kreatif dalam menanggapi isu kewarganegaraan.

2 Berpartisipasi secara aktif dan bertanggung jawab, dan bertindak secara cerdas dalam kegiatan bermasyarakat, berbangsa, dan bernegara, serta anti-korupsi.

3 Berkembang secara positif dan demokratis untuk membentuk diri berdasarkan pada karakter-karakter masyarakat indonesia agar dapat hidup bersama dengan bangsabangsa lainnya.

4 Berinteraksi dengan bangsa-bangsa lain dalam percaturan dunia secara langsung atau tidak langsung dengan memanfaatkan teknologi dan komunikasi.

Tujuan di atas dapat dicapai dengan melalui proses pembelajaran PKn baik formal, maupun informal. Hal ini menjadi tanggung jawab guru dalam proses pembelajaran dengan memberikan nuansa pembelajaran yang dapat mengarahkan tujuan PKn tersebut.

Berdasarkan karakteristik dari mata pelajaran PKn, sebenarnya mengisyaratkan bahwa kompetensi akademik siswa berupa kemampuan berpikir kritis menjadi sasaran dari pengembangan mata pelajaran tersebut. Keterampilan berpikir kritis merupakan kemampuan yang diharapkan dimiliki siswa pada saat menghadapi dunia nyata dimana siswa secara intelektual aktif dan terampil dalam memecahkan masalah, memberikan 


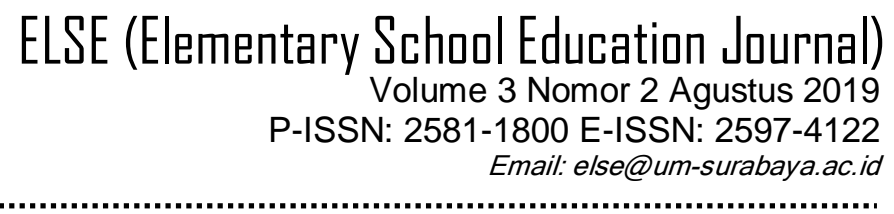

argumentasi, mengevaluasi informasi yang diperoleh baik dari pengamatan, pengalaman, penalaran dan komunikasi sebagai penentu perbuatan. Kemampuan berpikir kritis siswa dapat diajarkan di sekolah melalui proses pembelajaran misalnya pembelajaran PKn.

Mengembangkan kemampuan berpikir kritis siswa melalui pembelajaran PKn bukanlah hal yang gampang, melainkan membutuhkan ikhtiar dan daya inovatif pada guru selaku perencana dan pelaksana pembelajaran. Pendapat yang terkemuka pernah muncul di permukaan dunia pendidikan bahwa, Ward (dalam I Wayan Dasna dan Sutrisno: 2007) menyatakan pembelajaran berbasis masalah adalah suatu model pembelajaran yang melibatkan siswa untuk memecahkan suatu masalah melalui tahap-tahap metode ilmiah sehingga siswa dapat mempelajari pengetahuan berdasarkan masalah dan memiliki ketrampilan untuk memecahkan masalah. Dengan pembelajaran berbasis masalah siswa mampu berpikir kritis dan mengembangkan inisiatif.

Pembelajaran berbasis masalah mempunyai tujuan untuk mengembangkan dan menerapkan kecakapan yang penting yaitu pemecahan masalah berdasarkan keterampilan belajar sendiri atau kerjasama kelompok dan memperoleh pengetahuan yang luas. Guru mempunyai peran untuk memberikan inspirasi agar potensi dan kemampuan siswa dimaksimalkan.

Dalam teori tersebut, pembelajaran PKn hendaknya lebih memberikan kebebasan dalam berpikir dan mengarah kepada kemandirian siswa.Komponen penting yang hendak dikembangkan dalam pembelajaran PKn adalah membentuk warga negara yang cerdas (memilik pengetahuan kewarganegaraan), terampil (berpikir kritis dan berpartisipasi), dan berkarakter (loyal kepada bangsa dan negara, memiliki kebiasaan berpikir dan bertindak sesuai dengan pancasila dan UUD 1945).

Hal di atas dapat dicapai kalau guru mampu melakukan refleksi dalam pembelajaranya. Menjadi tugas guru untuk melakukan perubahan yang lebih baik agar pembelajaran lebih aktif dan mengembangkan kemampuan berpikir siswa. Salah satu model pembelajaran yang mengarah kepada kemampuan siswa berpikir secara kritis, rasional, dan kreatif dalam menanggapi isu global adalah dengan pendekatan pembelajaran berbasis masalah.

Namun, kenyataannya setelah dilakukan studi pendahuluan di Sekolah Dasar Kabupaten Sumenep tepatnya di Kecamatan Kota Sumenep, setelah ditanya kepada siswanya masih ada beberapa kendala dan permasalahan. Mereka menilai selama ini 
pembelajaran PKn terkesan kaku, kurang fleksibel, berisi hafalan dan membosankan. Hal yang sama juga di konfrontasikan kepada salah satu guru kelas VI, dalam kegiatan pembelajaran PKn siswa kurang mengarah pada konsep seperti pada saat membuat laporan penulisan, kurang focus pada masalah/ konsep, bahasa kurang komunikatif dan informasi pendukung kurang. Siswa kurang dapat bekerjasama dengan siswa lain saat mengerjakan tugas dengan kelompok ada siswa yang hanya duduk, diam bahkan ada yang ramai sendiri tidak ikut partisipasi dengan temannya. Kemampuan pemecahan masalah yang dimiliki siswa kurang. Hal ini dikarenakan aktifitas siswa selama kegiatan belajar mengajar lebih banyak menghafal materi sehingga dalam pembelajaran pemecahan masalah siswa masih bingung dengan tahapan pemecahan masalah terutama terletak pada rumusan masalah dan hipotesis. Ironisnya, guru yang bersangkutan enggan menggunakan variasi dalam mengajar.

Data di atas dapat diasumsikan atau hal ini tentu disebabkan karena kurang tahunya guru dalam menggunakan metode atau tidak ada keinginan melakukan perubahan yang lebih inovatif dalam pembelajaran. Permasalahan yang telah dikemukan merupakan dampak dari kegiatan pembelajaran yang kurang efektif. Dalam upaya meningkatkan kemampuan berpikir kritis siswa dalam kelas yang pada akhirnya berorientasi pada meningkatnya ranah kognitif, afektif dan psikomotorik terutama hasil belajar bidang studi PKn yang maksimal, maka para praktisi pendidikan telah memperkenalkan berbagai metode dan pendekatan mengajar yang diramu dalam suatu model pembelajaran yang sesuai dengan karakteristik pembelajaran dengan konsep pembelajaran berpusat pada siswa (student oriented). Dari berbagai model pembelajaran dapat dilihat bahwa pemilihan dan penerapan strategi pembelajaran yang digunakan mengalami pergeseran dari yang mengutamakan pemberian informasi (pemberian konsep) menuju ke strategi yang mengutamakan keterampilan berfikir untuk memperoleh dan menggunakan konsep (Hasan, 2005:30), sehingga dengan demikian peran guru dalam pembelajaran secara otomatis berubah, yaitu dari peran guru sebagai penyampai materi pelajaran (transformator) menjadi peran sebagai fasilitator (memfasilitasi siswa dalam belajar) atau dari teacher oriented menjadi student oriented.

Salah satu model pembelajaran yang berorientasi pada student oriented untuk meningkatkan mutu pembelajaran dalam mata pelajaran PKn adalah model pembelajaran yang berbasis masalah. Pada esensinya pembelajaran berbasis masalah adalah model 
pembelajaran yang berlandaskan konstruktivisme dan mengakomodasi keterlibatan siswa dalam belajar serta terlibat dalam pemecahan masalah yang kontekstual. Untuk memperoleh informasi dan mengembangkan konsep-konsep sains, siswa belajar tentang bagaimana membangun kerangka masalah, mencermati, mengumpulkan data dan mengorganisasikan masalah, menyusun fakta, menganalisis data, dan menyusun argumentasi terkait pemecahan masalah, kemudian memecahkan masalah, baik secara individual maupun dalam kelompok (Warsono, 2012:147).

Oleh karena adanya kesenjangan antara teori dan praktik serta eratnya pemilihan model dan metode pembelajaran yang harus relevan dengan peningkatan kemampuan berpikir kritis siswa maka menjadi penting untuk memilih dan menerapkan metode pembelajaran yang relevan dan efektif. Berdasarkan uraian tersebut, maka peneliti sangat tertarik untuk melakukan penelitian dengan mengetengahkan judul "Pengaruh Pembelajaran Berbasis masalah (Problem Based Learning) Terhadap Kemampuan Berpikir Kritis Siswa pada Mata Pelajaran PKn Kelas VI di SDN Kota Sumenep”.

Berdasarkan uraian latar belakang, pada penelitian ini dapat di ajukan sebuah rumusan masalah yaitu "Apakah ada pengaruh pembelajaran berbasis masalah (problem based learning)terhadap kemampuan berpikir kritis siswa pada mata pelajaran PKn kelas VI di SDN Kota Sumenep?".

Untuk mencapai pemecahan atas rumusan masalah yang di ajukan, maka dalam penelitian ini rumusan tujuan penelitiannya adalah untuk mengetahui seberapa besar pengaruh pembelajaran berbasis masalah (problem based learning) terhadap kemampuan berpikir kritis siswa pada mata pelajaran PKn kelas VI di SDN Kota Sumenep.

\section{METODE PENELITIAN}

Sesuai dengan judul dan rumusan masalah, maka penelitian ini termasuk dalam jenis rancangan penelitian eksperimental dengan desain penelitian Control group Pre-Test Post-Test Design. Menurut Arikunto, penelitian ini dapat melihat perbedaan pencapaian antara kelompok eksperimen dengan pencapaian kelompok kontrol.

Dalam penelitian ini yang menjadi populasi adalah siswa kelas VI SDN Kota Sumenep Tahun Ajaran 2015/2016. Sedangkan yang menjadi kelompok sampel adalah siswa kelas VI SDN Kota Sumenep Tahun Ajaran 2014/2015 sebanyak 2 sekolah, yaitu SDN Kolor II dan SDN Pajagalan I. 
Instrumen penelitian adalah alat atau fasilitas yang digunakan oleh peneliti dalam pengumpulan data agar pekerjaan lebih mudah hasilnya lebih baik dalam arti lebih cermat, lengkap dan sistematis sehingga lebih mudah diolah (Arikunto, 2006:149). Pada penelitian ini instrumen yang digunakan adalah tes kemampuan berpikir.

Instrumen penelitian sebelum digunakan, terlebih dahulu diuji cobakan untuk mengetahui validitas (rxy), reliabilitas (rii) yang berupa soal-soal. Setelah soal diuji cobakan selanjutnya soal tersebut dianalisis.

Untuk menguji hipotesis pada penelitian ini digunakan uji t. Uji t merupakan uji hipotesis untuk membandingkan dua keadaan atau dua keadaan diketahui, dengan cara menguji kesamaan dua rata-rata populasi. Namun sebelum diuji t, tentu di uji juga tentang uji normalitas dan uji homogenitas.

Rumus Uji t yang digunakan adalah:

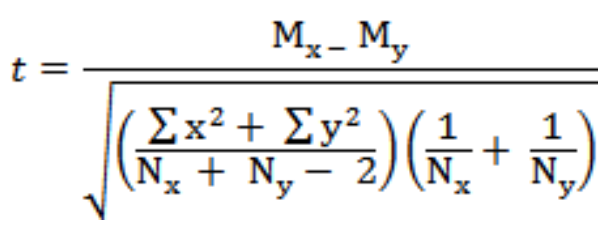

Keterangan:

$\mathrm{M}=$ nilai rata-rata hasil perkelompok

$\mathrm{N} \quad=$ banyaknya subyek

$\mathrm{X} \quad=$ deviasi setiap nilai $\mathrm{x}_{2}$ dan $\mathrm{x}_{1}$

$\mathrm{Y}=$ deviasi setiap nilai $\mathrm{y}_{2}$ dari mean $\mathrm{y}_{1}$

(Arikunto, 2006).

\section{HASIL DAN PEMBAHASAN}

\section{Hasil Validasi Perangkat Pembelajaran}

Berdasarkan hasil validasi terhadap 2 falidator diketahui, bahwa nilai rata-rata dari validator materi yang dibuat peneliti adalah 4 tergolong baik. Hali ini menunjukkan bahwa materi tersebut dapat digunakan untuk pembelajaran walaupun masih ada sedikit revisi dan saran dari validator. Materi ini dimaksudkan untuk menambah wawasan siswa terhadap materi yang dihubungkan dengan kehidupan sehari-hari yang diketahui oleh siswa.

Dalam pemvalidasian RPP, diperoleh bahwa nilai rata-rata dari validator adalah 4,2 termasuk kategori baik. Hal ini menunjukkan rencana pelaksanaan pembelajaran (RPP) yang telah dibuat layak digunakan untuk pembelajaran dalam penelitian. Sedangkan validasi TBK menunjukkan bahwa rata-rata Nilai penilaian lembar kerja siswa/TBK yang 
dilakukan oleh validator yaitu 4,1 dan termasuk kategori baik sehingga layak untuk digunakan dalam pembelajaran.

\section{Hasil Uji Coba Instrumen}

a. Uji Validitas

Uji validitas instrumen ini dilakukan dengan menghitung korelasi Nilai tiap item terhadap Nilai total sehingga diperoleh $\mathrm{r}$ hitung untuk tiap item dan ternyata dapat diketahui bahwa ada 10 item yang valid. Maka instrumen ini dapat digunakan dalam pengambilan data penelitian ini.

b. Uji Reliabilitas

Uji reliabilitas terhadap instrumen ini dilakukan uji Cronbach's Alpha, Berdasarkan ringkasan hasil analisis uji reliabilitas instrumen diatas diperoleh nilai Alpha sebesar 0,966 yang berarti jauh lebih besar dari 0,60. Dengan demikian simpulan hasil analisis dapat dinyatakan bahwa keseluruhan item instrumen adalah reliabel, dengan demikian instrumen penelitian cukup layak untuk digunakan mengambil data dalam penelitian.

\section{Hasil Uji Penelitian}

a. Uji Normalitas

Uji Normalitas terhadap data hasil penelitian ini dilakukan dengan teknik analisis uji Lillie (Kolmogorov-Smirnov Test), bertolak dari hasil proses analisis uji normalitas menunjukkan bahwa harga Sig diperoleh 0,200 berada diatas $\alpha 0,05$ maka disimpulkan gagal menolak $H_{0}$, yang berarti bahwa keseluruhan data menyebar normal (berdistribusi normal).

\section{b. Uji Homogenitas}

Sebelum melakukan uji hipotesis kesamaan rata-rata 2 populasi dengan uji-t 2sampel independen, masih perlu dipenuhi satu syarat lagi yakni dilakukan uji homogenitas varians. Dari hasil proses analisis uji homogenitas menggunakan Levenes's Test for Equality of Variances menunjukkan bahwa harga $\mathrm{F}$ diperoleh 0,452 dengan taraf signifikansi sebesar 0,504 yang kedudukannya berada di atas $\alpha 0,05$ maka hasil uji dapat disimpulkan gagal menolak $H_{0}$ yang berarti bahwa kondisi kedua sampel adalah homogen. c. Analisis Uji-t Pre-Test

Sebagaimana di atas telah dipaparkan bahwa data-data hasil penelitian telah memenuhi asumsi analisis statistika parametric, dengan uji-t 2-sampel independen. Bertolak dari hasil proses analisis data dan uji-t 2 sampel independen, diperoleh harga $t$ 
sebesar -1,207 dengan signifikansi 0,232. Selanjutnya dari hasil perbandingan dapat diketahui bahwa signifikansi t- hitung sebesar $0,232>\alpha 0,05$ maka hasil uji dapat disimpulkan gagal menolak $H_{0}$, yang berarti bahwa kedua sampel tidak berbeda secara signifikan.

Output di atas menunjukkan bahwa terdapat cukup bukti yang menyatakan bahwa rerata siswa pada kelompok kontrol dan rerata pada kelompok eksperimen tidak berbeda secara signifikan atau kedua kelompok memiliki performance yang sama.

\section{Uji Hipotesis}

Sebagaimana lazimnya dalam penerapan uji statistika parametric (uji-t 2 sampel independen) menuntut adanya beberapa asumsi yang harus dipenuhi, diantaranya pengujian normalitas pada kelas eksperimen dan control dilakukan dengan teknik analisis uji Lilliefors (Kolmogorof-Smirnov Test).

a. Hasil Uji Normalitas

Uji normalitas ini diperlukan sebagai persyaratan bagi teknik analisis data dengan menggunakan teknik analisis uji-t sampel (Statistik Parametik). Apabila data tidak normal, maka uji-t sampel tidak tepat diterapkan. Berdasarkan analisinya, bahwa hasil analisis seperti tertuang pada kolom Kolmogorov kelompok eksperimen mempunyai taraf signifikansi 0,200 sebagaimana pada kelompok kontrol juga yang kedudukannya diatas atau lebih besar dari nilai $\alpha=0,05$. Dengan demikian dapat disimpulkan bahwa data hasil penelitian berdistribusi normal.

b. Hasil Uji Homogenitas

Asumsi selanjutnya yang harus dipenuhi adalah kedua variable yang dibandingkan adalah memiliki varians yang homogen. Untuk itu dilakukan dengan uji Levene's Test for Equality of Variance yang ternyata dari hasil uji menunjukkan bahwa untuk masingmasing kelompok yang dibandingkan adalah homogen

Berdasarkan hasil analisis, bahwa mempunyai taraf signifikansi sebagaimana tampak pada kolom yaitu 0,487, yang kedudukannya berada di atas atau lebih besar dari nilai $\alpha=0,05$. Dengan demikian dapat disimpulkan bahwa kondisi data hasil penelitian adalah homogen. 
c. t-2 Sampel Independen

Dengan terpenuhinya asumsi penerapan uji-t 2 sampel independen, maka dapat dilakukan proses analisis yang secara lengkap dimaksudkan untuk melakukan uji hipotesis penelitian. Hasil analisis $\mathrm{t}$ tes sebesar 3,730 berdasarkan df 61 diperoleh $\mathrm{t}$ hitung pada taraf signifikansi 5\% sebesar 2,00 dengan demikian kedudukan t-tes 3,730>t-tabel 2,00 $(\alpha=0,05)$. Dapat disimpulkan bahwa probabilitas kesalahan dalam penelitian ini masih di bawah 0,05 .

Pengujian hipotesis dapat diputuskan, bahwa dengan tingginya harga t-hitung sebesar 3,730 memiliki taraf signifikansi 0,000 yang ternyata kedudukannya masih jauh berada di bawah nilai $\alpha=0,05$. Dengan demikian penelitian ini berhasil menolak $H_{0}$ pada taraf signifikansi 5\%. Selanjutnya dapat disimpulkan bahwa $H_{1}$ terbukti benar.

Mean dari pretes dan postes. Mean pada kelompok eksperimen adalah 54,38 dengan Std. Deviation 7,487, dan kelompok eksperimen adalah 74,38 dengan Std. Deviation 7,594. Sedangkan mean kelompok kontrol adalah 51,94 dengan Std. Deviation 8,532 dan kelas kontrol adalah 66,94 dengan Std. Deviation 8,234. Hal ini membuktikkan bahwa terjadi peningkatan pada kelas eksperimen yang telah diberikan perlakuan dengan model pembelajaran berbasis masalah. Mean dari kelompok eksperimen lebih besar daripada kelompok kontrol $(74,38>66,94)$. Mean pada kelompok kontrol dengan menggunakan model pembelajaran konvensional, juga mengalami peningkatan akan tetapi peningkatan pada kelompok kontrol kurang optimal dan masih belum dapat dikatakan mencapai tujuan pembelajaran atau belum menunjukkan peningkatan yang signifikan. Dengan demikian dapat disimpulkan kemampuan berpikir kritis siswa pada kelompok eksperimen lebih tinggi daripada kelompok kontrol. Model pembelajaran berbasis masalah berpengaruh positif terhadap kemampuan berpikir kritis siswa.

\section{KESIMPULAN DAN SARAN}

Model pembelajaran berbasis masalah (problem based learning) berpengaruh positif terhadap kemampuan berpikir kritis pada pembelajaran PKn siswa kelas VI Sekolah Dasar Negeri Kota Sumenep. Selanjutnya, hasil dari penelitian masih dinilai memiliki keterbatasan, sehingga disarankan butuh penelitian lebih lanjut utamanya terkait variasi dalam pembelajaran yang berbasis masalah dan ruang lingkup penelitian yang lebih luas. 


\section{ELSE (Elementary School Education Journal) \\ Volume 3 Nomor 2 Agustus 2019 \\ P-ISSN: 2581-1800 E-ISSN: 2597-4122 \\ Email: else@um-surabaya.ac.id}

\section{DAFTAR PUSTAKA}

Depdiknas. 2003. Pengajaran Berdasarkan Masalah. Jakarta: Departemen Pendidikan Nasional.

Hasan, S.H. 2005. Evaluasi Kurikulum. Jakarta : P2LPTK Ditjen Dikti-Depdikbud.

I Wayan Dasna \& Sutrisno. 2007. Pembelajaran berbasis masalah. Dari http://lubisgrafura.wordpress.com/2007/09/19/. Diambil tanggal 10 Desember 2014.

Sardiman. 2000. Interaksi dan Motivasi Belajar Mengajar. Jakarta: Grafindo Persada.

Savage, T. V. \& David G. Armstrong. 1996. Effective teaching in elementary social studies. (third edition). New Jersey: A Simon \& Schunter Company.

Suharsimi, Arikunto. 2006. prosedur penelitian suatu pendekatan Praktik. Rineka cipta. Jakarta.

Tilaar, H. A. R. 2001. Manajement Pendidikan Nasional. Bandung: PT Remaja Rosda karya.

Warsono \& Hariyanto. 2012. Pembelajaran Aktif, teori dan asesment. Bandung. PT. Remaja Rosda Karya.

Udin S. Winaputra. 2005. Materi dan Pembelajaran PKn SD. Jakarta: Universitas Terbuka. 